\title{
Editor Sebagai Sutradara, Analisis Semiotika Pada “Buku Tanah Air Kita "
}

\author{
Bayyinah Nurrul Haq \\ Fakultas Industri Kreatif \\ Universitas Trilogi
}

\begin{abstract}
Editor in the publishing world has function to keep the consistency of story line and point of view. "Tanah Air Kita" is a book published by N.V. W. van Hoeve-Bandung that contain the work of local and foreign photographers since Dutch colonial rule until Indonesia's independence.

The research aims to discuss how the role of editor in producing a book that fits his vision about how Indonesia is supposed to be in a photo and how observers interpret. Using semiotic analysis based on the model spectator - operator-spectrum. Analysis is done by categorizing photo illustration in 4 parts, which are :nature beauty,technology-natural resources, how people work, political change, then cross-checked upon their stadium- punctum.
\end{abstract}

Selected photos shows the vision of N.A. Douwes Dekker about his expectation towards Indonesia, as the new nation that wants to be reckoned in the world, according to the presences.

Keywords :Editor ,Punctum, Operator, Spectator, Studium.

\section{PENDAHULUAN}

\section{Latar Belakang Masalah}

Peranan editor sangatlah kritis pada terbit tidaknya sebuah naskah. Dalam dunia penerbitan, editor mempersiapkan sebuah naskah agar memenuhi kriteria untuk dipublikasikan, baik kriteria yang berhubungan dengan visi misi penerbit maupun yang berhubungan dengan kebutuhan pasar dan aspek teknis penerbitan. Peran lainnya adalah menjaga agar alur cerita dan sudut pandang berada pada benang merah atau konsep buku yang sama.
"Tanah Air Kita", adalah buku yang diterbitkan oleh N.V. Penerbitan W.Van Hoeve, Bandung. Diduga diterbitkan pertengahan tahun 1951an, namun dalam buku tersebut pada salah satu bagiannya membahas Timor - Timur sebagai bagian dariRepublik Indonesia,kemungkinan sudah melewati tahun 1960an. Walaupun beberapa foto menunjukan keadaan Indonesia saat masih dijajah Belanda. Buku ini memvisualisasikan kemegahan Indonesia dalam bentuk foto yang menampilkan kekayaan alam dan kekayaan budaya. Hal yang membuatnya berbeda adalah "cita rasa" nasionalisme yang terbawa dalam karya foto maupun isi 
keseluruhan dari buku tersebut. Foto yang terdapat pada buku " Tanah Air Kita" sebagian besar karya fotografer asing (Belanda), dan beberapa merupakan karya pribumi. Keunikan dari buku ini adalah adanya upaya membangun identitas baru Indonesia setelah melewati masa kemerdekaan dan revolusi fisik. Sejak awal buku ini tidak ditujukan untuk menjadi referensi ilmiah, ensiklopedi ataupun laporan jurnalistik mengenai Indonesia. Buku ini hanya ditujukan untuk mendapatkan kesan di hati pembacanya.

Buku "Tanah Air Kita", tidak mencantumkan editor atau pengarangnya, hanya mencantumkan N.A. Douwes Dekker sebagai penyusun buku. Peran N.A. Douwes Dekker dalam penyusunan buku adalah membuat narasi dan memilih foto yang akan ditampilkan pada buku tersebut. Foto - foto yang ditampilkan adalah koleksi pribadi dari N.A Douwes Dekker selama ia bekerja di Indonesia serta bantuan dari pihak lain. Sistem penerbitan buku di Indonesia sebelum tahun 1980an tidak mengenal posisi editor. Pada masa itu peran editor dalam proses penerbitan naskah cenderung melebur dengan penyusun naskah. Buku Tanah Air Kita diduga diterbitkan tahun 1950an, memungkinkan peran rangkap N.A. Douwes Dekker, sebagai penyusun buku secara keseluruhan, pembuat narasi, penyortir foto juga editor.

Foto-foto yang ditampilkan disusun tidak berurutan sesuai timeline sejarah
Indonesia pada umumnya. Semua foto ditujukan untuk memperlihatkan suasana dan rasa yang sesuai dengan tema tiap bab. Kuatnya suasana dan rasa pada foto yang ditampilkan berkaitan dengan tema yang dipilih, kesesuaian dengan narasi dan teknik pengambilan gambar. Namun, pada beberapa foto ditemukan beberapa hal yang aneh, ganjil dan terkadang terkesan mengganggu.

Dalam pembahasan karya - karya fotografi, fenomena di atas, berhubungan dengan studium dan punctum. Istilah ini diperkenalkan Roland Barthes pada buku terakhirnya Camera Lucida (1980). Studium adalah hal - hal yang ada pada foto yang membuat pengamat menyukai foto tersebut.Sedangkan punctum adalah hal unik, ganjil yang bersifat mengganggu. Kadang punctum bersifat ekspansif yang dapat mengganggu foto secara keseluruhan. Gangguan yang diberikan oleh punctum tidak selalu bersifat negatif, karena hal ganjil ini seringkali dilatarbelakangi pengalaman pribadi pengamat. Keberadaan punctum dapat menjadi semacam "pengikat", antara foto dengan pengamatnya.Kehadiran punctum dapat mempengaruhi berhasil tidaknya buku Tanah Air Kita membangun komunikasi personal dengan pembacanya.

\section{Kerangka Pemikiran}

Berdasarkan asumsi di atas, tulisan ini akan membahas tentang foto - foto yang ada di buku Tanah Air Kita dengan mencari studium dan punctumnya dan dihubungkan dengan peran 
editor - penyusun buku, yang tercermin di bagian mukadimah buku tersebut.

Pendekatan semiotika yang akan dipergunakan sebagai alat untuk menganalisis karya tersebut mengacu pada pendekatan yang dilakukan oleh Roland Barthes terhadap karya -karya kategori fotografi. Ruang lingkup karya yang akan dibahas adalah foto foto yang ada pada buku "Tanah Air Kita", dengan mempertimbangkan konteks industri penerbitan saat itu, kondisi sosial budaya Indonesia saat itu, termasuk latar belakang N.A.Douwes Dekker yang bertindak sebagai penyusun buku tersebut. Karena keterbatasan ruang, pembahasan akan mengambil beberapa sampel foto yang dianggap mewakili tujuan penulisan yaitu mencari studium dan punctum yang dapat menguatkan upaya "berkesan dalam hati" dan "melukiskan suatu daerah".

\section{STUDI PUSTAKA}

\section{Pendekatan Semiotika untuk karya Fotografi.}

Fotografi dengan perkembangan teknologinya dianggap sebagai alat untuk menyimpan sebuah momen dalam bentuk gambar mati yang akan selalu sama tetapi akan mengalami pemaknaan yang berbeda-beda. Menurut Barthes mengamati karya fotografi, melibatkan tiga hal, yaitu Operator, orang yang membingkai potongan keyataan dan mengambil gambar, spectator orang yang melihat gambar danspektrum adalah orang yang menjadi subjek gambar. Analisis karya fotografi akan melibatkan dua hal yaitu Studium dan punctum. Kedua istilah ini muncul dalam buku Barthes, "Camera Lucida"(Schneider dan Laurie, 1996, p.89).

Studium adalah elemen yang membuat sebuah karya fotogarfi menjadi menarik. Umumnya hal ini sesuatu yang sudah direncanakan untuk menarik minat pengamat. Melalui elemen studium pengamat akan menyukai karya foto tersebut, tetapi hanya mencapai level menyukainya saja tidak lebih. Punctum diartikan sebagai pemaknaan terhadap detail - detail foto yang membangun hubungan antara objek atau orang yang ada dalam karya foto tersebut. Sebenarnya punctum berjalan searah dengan studium tetapi cenderung bersifat sebagai "pengganggu", membangun el emen yang muncul dari gambar/scene dan tanpa sengaja mengisi seluruh karya dengan itu. Punctum cenderung memiliki kekuatan yang lebih besar dan memaksa terhadap spektator, untuk mengubah "suka" menjadi "cinta" terhadap sebuah karya foto.

Proses komunikasi yang terjadi pada punctum lebih bersifat bebas tidak berstruktur karena akan melibatkan hal yang bersifat personal dari spektator terlepas dari konteks lingkungan, budaya, bahasa dan politik. Proses komunikasi yang terjadi antara fotografer sebagai operator akan terbalik dengan proses komunikasi yang terjadi pada spektator atau pengamat. Bila 
operator memikirkan bagaimana sebuah pesan disampaikan dalam bentuk karya fotografi, maka spektator memikirkan pesan yang disampaikan oleh operatormelalui proses interpretasi. Pada proses interpretasi ini, cenderung bersifat strukturalis, karena melibatkan kode yang berhubungan dengan konteks budaya sangat mempengaruhi bagaimana antara keduanya menginterpretasikan sebuah pesan dalam bentuk foto.

\section{Penerbit, Editor, Dan Fotografer}

Industri penerbitan melibatkan beberapa pihak, yaitu, penulis atau pengarang, penerbit buku (publishing house), percetakan (printing house), distributor buku, agen / toko buku, klub baca buku / komunitas, pembaca. Jejaring kerja inilah yang akan mempengaruhi bagaimana buku membawa pesan bagi pembacanya. Penerbit, bertindak sebagai konseptor sebuah buku, mempersiapkan proses penerbitan sejak berupa ide yang dikembangkan dalam konsep, memproduksi buku hingga melakukan distribusi dan promosi buku tersebut pada pembaca yang dijadikan target (Trim, 2009, p.9).

Editor adalah penyunting buku, bertindak untuk membuat koreksi, menyusun naskah. Menyunting sendiri merupakan sebuah aktivitas mempersiapkan naskah agar menjadi bahan publikasi siap terbit atau layak baca. Termasuk di dalamnya menyusun / menata, memperindah hingga layak untuk ditampilkan dimuka umum. Seorang editor melayani penulis, penerbit dan pembaca sasaran. Filosofi kerja editor adalah mengkomunikasikan ide / gagasan para penulis / pengarang secara mudah, jelas, benar, serta tepat kepada pembaca dengan sasaran prinsip menebarkan ilmu dan informasi yang bermanfaat untuk kemaslahatan public (Trim , 2009, pp 23-26).

Pada jaringan kerja industri penerbitan, editor dapat berperan sebagai operator terhadap foto-foto yang disusunnya. Dalam pembahasan teori Barthes, fotografer berperan sebagai operator saat ia mengambil gambar dalam industri penerbitan, editor mengambil peran tersebut. Karena kegiatan menyunting naskah meliputi aspek kebahasaan dan piktorial. Hal ini sesuai dengan kegiatan dasar menyunting, yaitu pemakluman (first reading), perbaikan, pengubahan, pengurangan dan penambahan pada naskah (Trim, 2009,pp.34-38).

\section{METODE PENELITIAN}

Penelitian menggunakan metode kualitatif dengan menggunakan analisis semiotika berdasarkan model operator - spektator - spektrum dan studium - punctum. Data utama didapatkan melalui dokumentasi buku Tanah Air Kita (TAK) ditunjang dengan data dari buku lainnya yang dirujuk dalam buku Tanah Air Kita atau melalui pembahasan di internet.

Ilustrasi foto dibagi ke dalam 4 kategori, yaitu keindahan alam, 
kekayaan alam - pemanfaatan teknologi untuk SDA, perubahan budaya-perubahan proses politik dan kemajuan teknologi. Kemudian setiap kategori dibahas berdasarkan informasi yang ingin disampaikan operator pada spektator. Dilanjutkan dengan informasi yang diterima spektator dibagi ke dalamstudium dan punctum-nya. Hubungan antara informasi yang disampaikan oleh operator disesuaikan dengan tujuan awal buku yaitu, sebagai informasi tentang "Indonesia dengan identitas baru yang kena di hati".

\section{GAMBARAN UMUM}

\section{Buku "Tanah Air Kita"}

Menurut data perpustakaan Cornell University, buku Tanah Air Kita (TAK) disusun oleh N.A. Douwes Dekker, pada masa Indonesia baru melewati revolusi fisik. Diduga diterbitkan tahun 1951, dalam dua edisi. Edisi berbahasa Indonesia dengan judul Tanah Air Kita The Hague: J W. Van Hoeve, Ltd. versi lainnya menyebutkan TAK versi Indonesia diterbitkan oleh Penerbitan W. Van Hoeve, Bandung's Gravenhage pada tahun 1941, edisi kedua dibuat tahun 1952 ada yang menyebutnya tahun 1950, edisi berbahasa Belanda dengan judul Land en Volk van Indonesië. TAK dilukiskan sebagai buku yang berupaya menggambarkan kehidupan dan kebudayaan di Indonesia:

"Buku tanah air kita merupakan buku yang menggambarkan kehidupan dan budaya dari rakyat dari sebuah bangsa yang baru lahir yaitu Indonesia, dan didalamnya menegaskan pandangan Douwes Dekker tentang heterogenitas Indonesia melalui berbagai foto yang tersebar luas dalam berbagai topik dan masalah". (Cornell 2012),

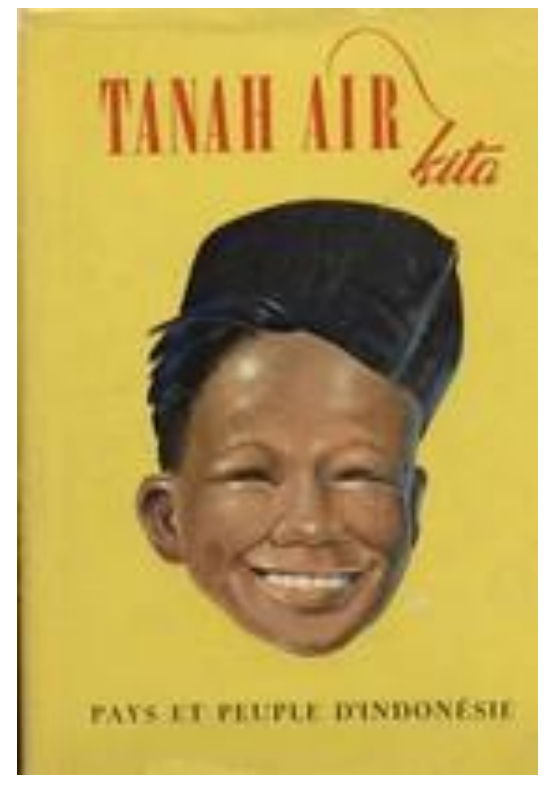

Gambar 1. Sampul buku Tanah Air Kita

Dalam dokumen yang sama ditegaskan terdapat penguranganpengurangan yang dianggap perlu oleh Douwes Dekker dalam penyusunan buku tersebut, yaitu ketiadaan foto-foto Indonesia pada masa revolusi fisik. Padahal buku tersebut diterbitkan tepat beberapa tahun setelah revolusi fisik di Indonesia usai. Kemungkinan keputusan Douwes Dekker untuk menghilangkan episode revolusi fisik adalah upayanya untuk tetap netral diantara dua faksi yang berbeda.

"Keputusan Douwes Dekker untuk mengeluarkan gambar - gambar ini tidak dapat disangkal sebagai bagian dari masalah sensitivitas politis, kemudian membuatnya untuk memutuskan memilih Cornell sebagai 
tempat penyimpanan koleksi foto hasil karyanya. Di perpustakaan Cornell University tidak akan terjadi monopoli terhadap karya-karyanya oleh faksi manapun" (Dekker, 1951, p.8).

Buku dengan tebal 320 halaman berukuran $22 \times 31 \mathrm{~cm}$, memiliki berat $1.57 \mathrm{gr}$, hard cover berisikan potret potret dari karya 318 fotografer. Buku berisikan naskah pengantar dengan ilustrasi foto hitam putih dan peta Wilayah Republik Indonesia. Dibagi dalam 8 Bab, yaitu : Selayang pandang; Raksasa muda; Bisikan air menepi; Anggrek kattu'listiwa (ejaan sesuai buku asli); Taman laut dan burung cenderawasih; Tapak kuda menggentar bumi; Gambang bernyanyi; Tachta para dewata; Ratna penjambung rangkaian zamrud. Sampul depan terdiri dari dua bagian sampul kertas dan jilid hard cover, terdapat dua versi sampul luar yaitu bergambar wajah anak laki-laki dan penari dalam bingkai ukiran kayu.

Gambar sampul belakang buku TAK adalah Garuda Pancasila sebagai ikon Bhinneka Tunggal Ika. "Pancasila sampai detik ini adalah sumpah suci harga mati untuk NKRI". Pada bagian kata pengantar diungkapkan betapa sulitnya penyusunan buku ini, hingga dianggap mustahil untuk diterbitkan. Indonesia dengan berbagai perbedaan yang ada dan sejarah yang panjang, membuatnya begitu banyak tarik menarik dalam prosesnya.

"Sebab belum pernah seperti sekarang terasa kebutuhan akan sebuah kitabbergambar tentang Indonesia-karena berachirnya suatu masa kegaduhan dan kesalah pahaman dunia ingin memperbaharui perkenalanja dengan Indonesia. Belum pernah sekian luka2 perlu diberi ramuan obat jang halus jang disediakan oleh Ibu Indonesia jang Indah Permai dan murah hati. Oleh sebab itu lahirlah "tanah Air kita" tanpa mempedulikan apa sadjaberkat mereka yang member nasehat dan bantuan..." (Dekker : 1951, 1).

Selanjutnya buku TAK menjadi semacam buku koleksi yang cukup komprehensif dalam menggambarkan kehidupan Indonesia di awal masa kemerdekaannya.

\section{Riwayat Hidup dan karya - karya N.A.Douwes Dekker}

Niels Alexander Douwes Dekker lahir di Batavia tahun 1911. Ia adalah cucu sepupu dari Multatuli - Edward Douwes Dekker. Memulai pendidikannya di Bandung kemudian melanjutkan pendidikan arsitektur di Delft dan the Hague. Lalu, ia bekerja sebagai fotografer profesional, seniman, pembuat film esai dan humas profesional. Ia sempat bekerja pada pemerintah Hindia Belanda sebagai kepala dari The Netherlands East Indies Visual Information Service. N.A. Douwes Dekker memiliki minat kuat pada dokumentasi kehidupan religius masyarakat Indonesia, terutama yang berhubungan dengan ritual kematian, pemakaman. Salah satu karyanya adalah koleksi ritual kematian suku Dayak di Kalimantan- Tiwah, Sulawesi, Bali dan pulau lainnya. 
Koleksi karyanya mencapai 260 karya fotografi.

Tahun 1949, merupakan puncak dari kekacauan politik dan keamanan di Indonesia. Ia memutuskan mengirim semua dokumennya dalam beberapa karung dan kotak tanpa keterangan atau pemilahan apapun dengan bertuliskan "milik pribadi Douwes Dekker" pada rekannya Anne Schiller di Cornell University. Universitas ini menggunakan pembabakan yang ada pada buku TAK sebagai acuan untuk menyusun koleksi karya N.A. Douwes Dekker, karena buku ini merupakan karya Douwes Dekker yang dianggap cukup runtut dalam menjelaskan perjalanan sejarah Indonesia dalam sudut pandang Douwes Dekker.

N.A.Douwes Dekker memilih tinggal di Amerika Serikat dan meninggal disana. Semua koleksi karyanya disumbangkan ke perpustakaan Cornell University, tersimpan sebagai koleksi Division of Rare and Manuscript Collections, Cornell University Library termasuk didalamnya 8000 dokumen meliputi foto, negatif foto, buletin Government Information Service $(R V D)$,berita yang dirilis, dan material lainnya yang berhubungan termasuk laporan polisi, perintah perintah komandan, dan dokumen surat-menyurat.

\section{Penerbit N.V. Van Hoeve}

N.V.Van hoeve adalah penerbit dengan spesialisasi menerbitkan buku referensi, beroperasi sejak masa penjajahan Belanda. Pada tahun 1950an karena perubahan politik nasionalisasi perusahaan, N.V.Van Hoeve memilih berhenti beroperasi. Kemudian tahun 1970an beroperasi kembali, berubah nama menjadi PT.Ichtiar Van Hoeve (IVH). PT.IVH adalah penerbit pertama yang menerbitkan ensiklopedi Indonesia. Mereka berkeyakinan bahwa bangsa yang maju adalah bangsa yang memiliki ensiklopedinya sendiri.

\section{HASIL DAN ANALISA}

\section{Tema Keindahan Alam}

Sampel yang diambil adalah halaman 164, 166 dan 167. Ketiga halaman berada dalam Bab Sunda Ketjil. Halaman yang berurutan ini diberi jeda satu halaman, kemudian kita akan menemukan serangkaian foto yang masih dalam cerita yang sama sebagaimana terlihat di bawah ini. 

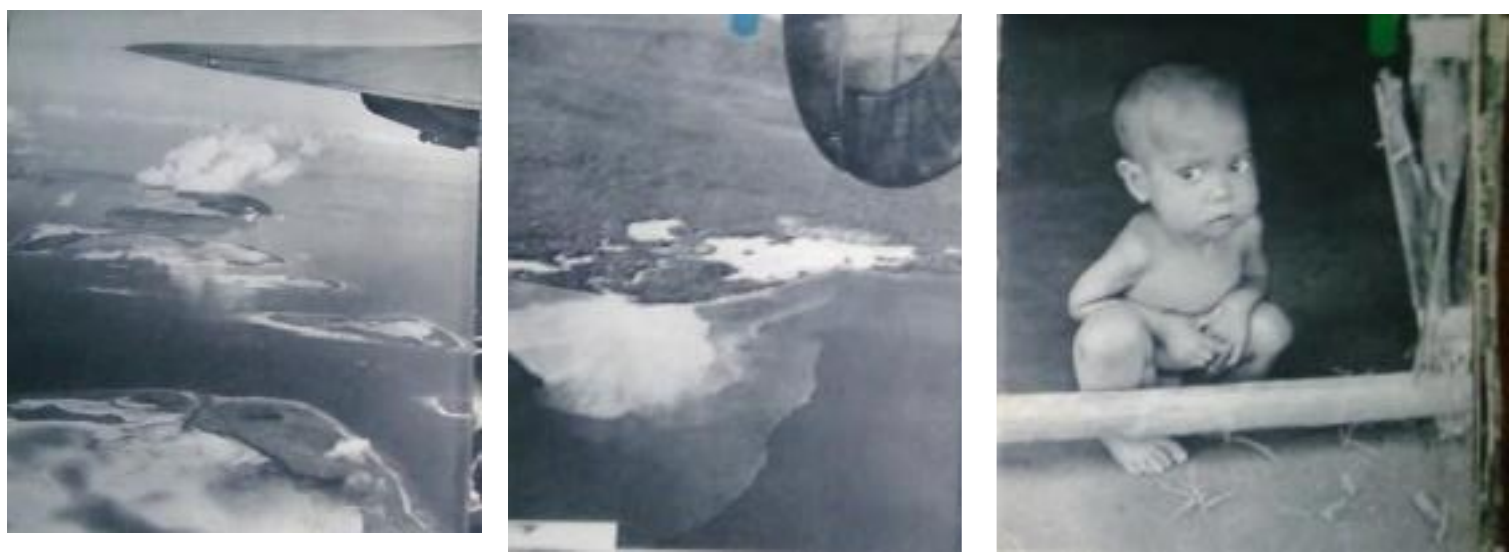

Gambar 2. Foto pada halam buku Tanah Air Kita

Operator : Mencoba memperlihatkan megahnya kepulauan Indonesia di tengah - tengah luasnya lautan. Rangkaian pulau di Indonesia Timur yang berada diantara rangkaian terumbu karang yang membentuk cincin - atol. Foto udara menegaskan luas dan megahnya kepulauan Indonesia Timur dengan sudut pandang dari atas Pulau yang dituju makin dekat, mulai terlihat jelas garis pantai pulau Seram.

Anak masih batita, ekspresi takut dan bingung, berada di dibawah berjongkok dengan tangan dikepal erat -erat.Kondisi ini diberi caption yang menjelaskan rasa curiga anak tersebut dan niat baik operator yang tidak dipahami si anak.

Spektrum : Sayap pesawat terlihat sebagian, seolah-olah menunjukkan operator (fotografer) berada di dalam pesawat. Ekor pesawat yang terlihat lebih besar proporsinya dibandingkan sayap pesawat yang terlihat di halaman sebelumnya.
Spektator - Studium : Melihat foto lautan luas dengan pulau - pulau kecil yang tersebar diantara bagian putih. Setelah membaca caption baru diketahui bahwa bagian putih itu adalah atol, kecuali spektator sudah memiliki pengetahuan tentang itu.

Spektator - Punctum : Sayap pesawat, pesawat punya siapa ? (p.164, p.166) tidak ada pembahasan di caption. Ekspresi ketakutan spektrum terlihat jelas pada mata yang masih berlinang air mata, tangan yang dikepalkan erat - erat menyiratkan ketakutan, bukan curiga.Takut umumnya terjadi pada hal yang bersifat asing dan jauh berbeda dengan yang biasa ada dalam keseharian. Apakah orang yang benar-benar asing yang dihadapi anak kecil tersebut?

\section{Tema Kemajuan Teknologi Pemanfaatan Sumber Daya Alam} Sampel diambil dari halaman 248 dan 249. Merupakan halaman dengan sekuens berurutan langsung. 

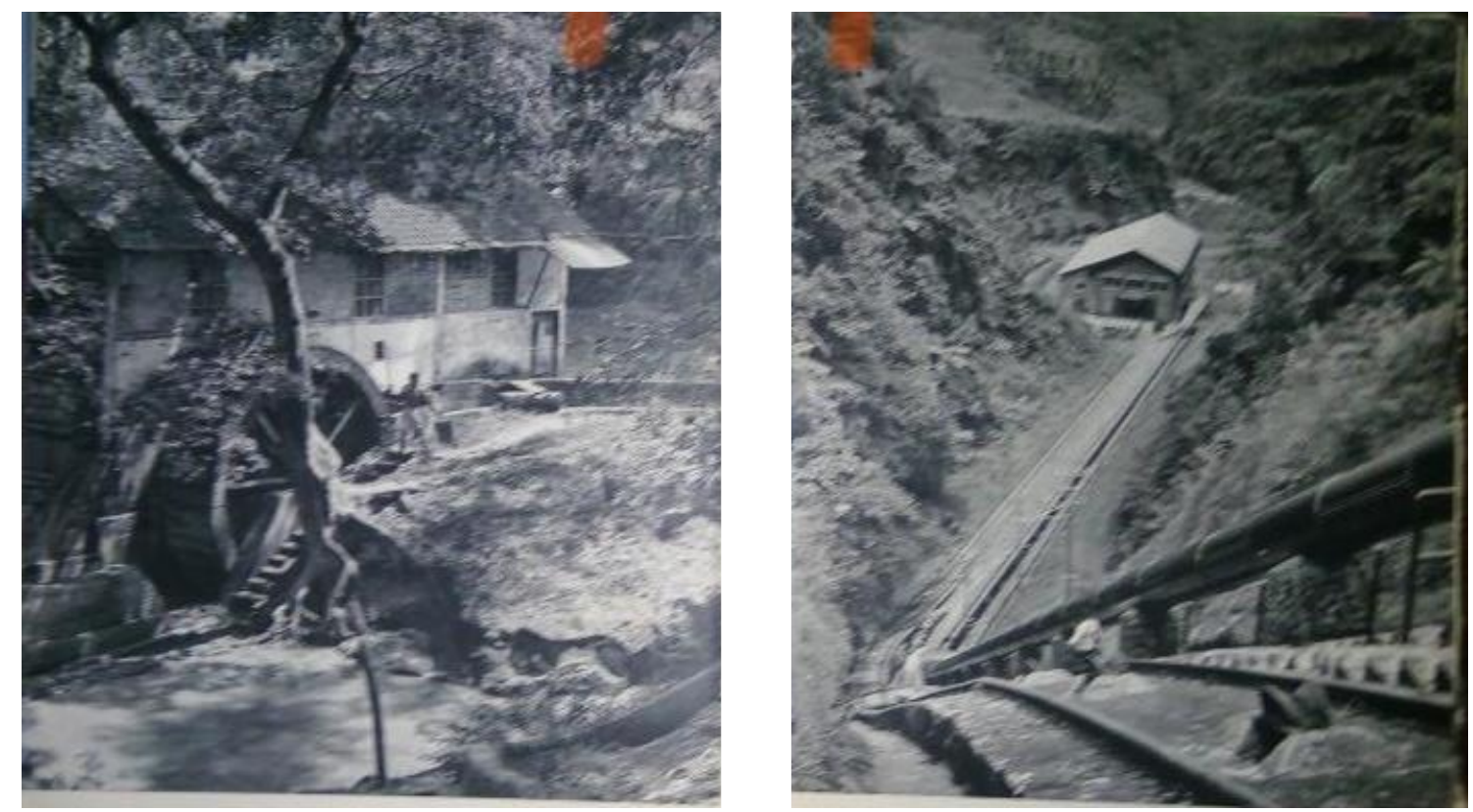

Gambar 3. Foto Pemanfaatan SDA (kanan p.,248, kiri p.249, 2012)

Operator : Menginformasikan bangsa Indonesia sudah dapat memanfaatkan sumber daya alam nya menjadi sumber energi. Pemanfaatan teknologi yang sama dengan versi modern namun dalam bentuk dan skala yang lebih sederhana. Pemanfaatan teknologi dengan skala dan tingkat yang lebih besar. Penyusunan berurutan, recto-verso menguatkan kontras antara kedua nya. Posisi tubuh manusia yang berbeda terhadap spektator menguatkan perbedaan skala, karena posisi tubuh ini seakan menjadi penunjuk arah untuk menyadari perbedaan skala.

Spektrum : Posisi tubuh yang berbeda menghadap spectator ,membelakangi spektator.

Spektator - Studium : Indonesia sudah tersentuh teknologi pemanfaata SDA, air. Kincir air yang terlihat kotor dengan kondisi air tidak terlalu deras (tidak menghasilkan tenaga yang kuat) terlihat kontras dengan teknologi yang lebih maju, lebih besar. Suasana disekitarnya yang terang benderang, air yang mengalir deras menunjukkan kekuatan yang besar. Posisi tubuh spektrum yang membelakangi spektator seakan menunjukkan ia sedang berjalan terus ke depan, menguatkan kesan bahwa dia masa depan energi bagi Indonesia. Memberikan rasa optimisme terhadap kejayaan bangsa Indonesia ke depannya sebagai penggambaran masa depan bangsa.

Spektator - Punctum : Kincir air yang terlihat kotor, sepertinya sudah tidak beroperasi dengan baik. Akan menjadi masa lalu?. Hal ini senada dengan caption pada foto tersebut yang menganggapnya sebagai "pemandangan yang menarik hati" dan "alat yang dihormati sebagai pelopor tenaga listrik". 
Tema Budaya - Perubahan Proses Politik

Sampel yang diambil adalah halaman 234 dan 235. Berada pada Bab "Tachta Para Dewata". Menggambarkan tentang perubahan proses politik dari politik yang kental dengan budaya bangsa Indonesia ke politik modern yang lebih demokratis.

Operator : Menunjukkan proses politik yang terjadi dalam tradisi ulama Madura. Komplek makam keramat dijadikan tempat muktamar. Beberapa makam dihiasi ukiran kaligrafi dan ditutupi kain yang diikat pada tiang atap makam. Semua duduk dengan takzim menghadap makamyang kain penutupnya tersingkap hingga memperlihatkan sebagian nisannya(p.234).

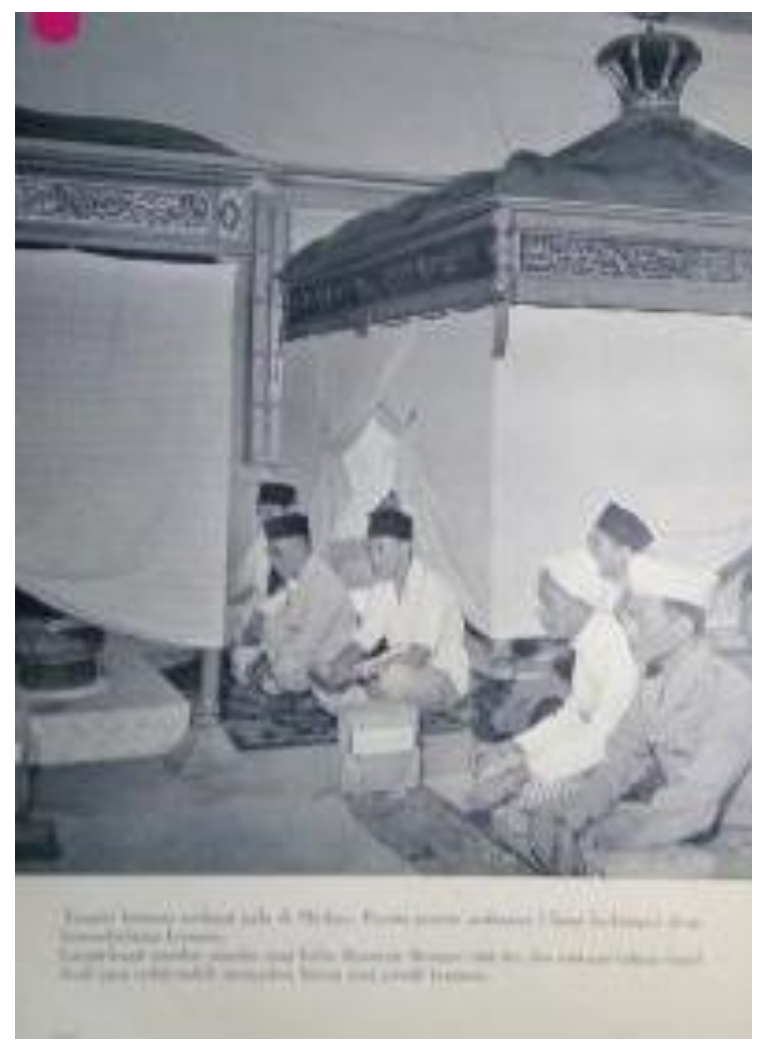

Foto pria tua yang melangkah keluar,dari pintu yang tirainya tersingkap. Ekspresi senyum lega dan gestur langkah kaki yang ringan dan riang. Di sebelahnya ada pria berkacamata hitam berbaju setelah putih-putih sedang memukul kentongan (p.235).

Spektrum : Posisi duduk bersila, takzim, sebagian menunduk sebagian menatap lurus kearah makam yang penutupnya tersingkap (p.234). Ekspresi bahagia, riang dan lega, hampir semua menatap pria yang melangkah keluar ruangan (p.235).

Spektator - Studium : Proses politik yang masih terikat tradisi, dilakukan di tempat khusus yang dikeramatkan dan hanya orang tertentu, yang

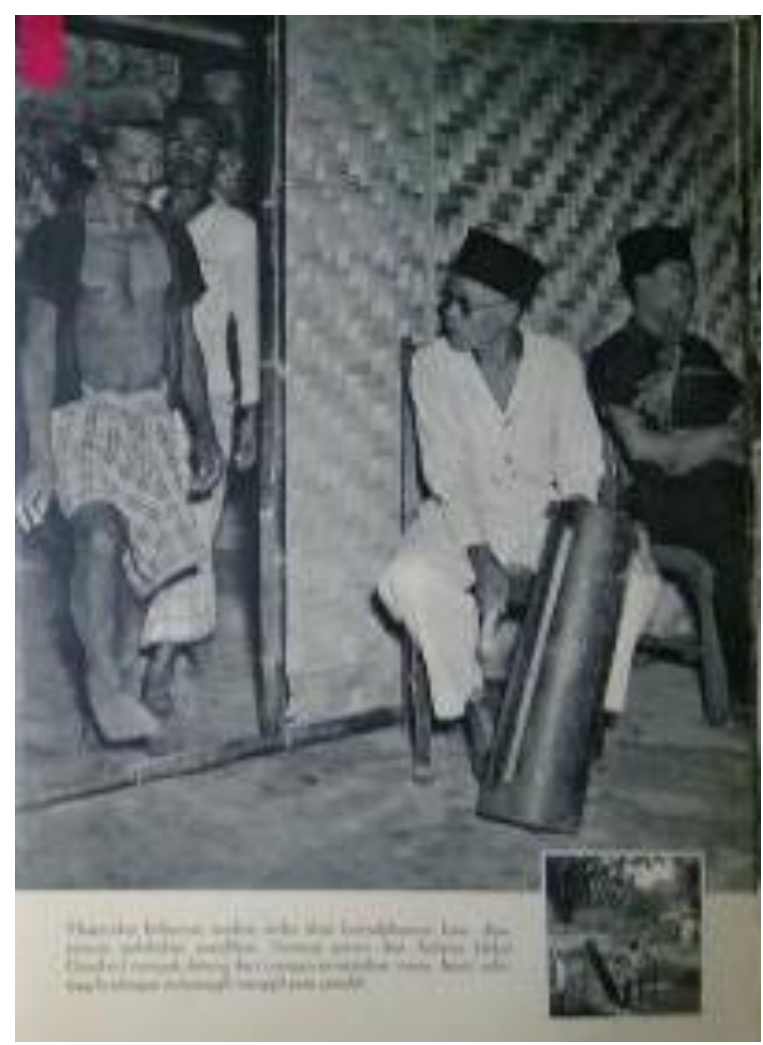

Gambar 4. Foto Perubahan proses politik (kanan p.,234, kiri p.235, 2012) 
berpeci, bersorban. Suasana yang terasa adalah keheningan, khusyu takzim (p.248). Penggambaran suasana riang, penuh kelegaan pada saat PEMILU pertama Indonesia. Diperlihatkan ekspresi dan gestur riang penuh rasa lega (p.249).

\section{Spektator-Punctum : Pria}

berkacamata yang menatap lurus ke arah depan, tempat adanya makam yang tutupnya tersingkap. Apakah itu artinya meyakini, atau mengacu pada sesuatu yang sudah tidak adanisan-orang mati-keramat (p.234). Caption hanya menjelaskan itu sebagai muktamar ulama Madura yang dilaksanakan di makam keramat, caption tidak terlalu berhubungan dengan punctum yang muncul di foto. Ada urutan unik antara pemilih (pria yang keluar ruangan) - pria yang memukul kentongan dengan Pria di sebelah pemukul kentongan. Pria di sebelahnya itu seperti memiliki ruangnya sendiri, posisi duduk menyamping ke arah yang berbeda, tatapan mengarah ke tempat yang jauh. Uniknya, pria yang melangkah ke luar (pemilih) menggunakan pakaian yang sederhana, bercelana pendek dengan peci menyamping. Sedangkan pria pemukul kentongan memakai setelan putih - putih berkacamata (terpelajar - aparat), sedangkan pria di sebelahnya memakai kemeja hitam, celana hitam sedang memeluk wayang. Apakah pria itu dalang? Penguasa tidak terlihat? (p.235). Caption tidak membahas pria ini, tetapi lebih menguatkan informasi pria pemukul kentongan, dilengkapi dengan inset proses pemanggilan pemilih pada masa itu dengan alat kentongan.

\section{Tema Perubahan Dalam Teknologi Peralatan Kerja}

Sampel yang diambil adalah foto pada halaman 308 dan 309, berada pada bagian "Ratna Penyambung Rangkaian Zambrut", merupakan pembahasan tentang Jawa Barat.

Operator : Menjelaskan perubahan peralatan konstruksi yang digunakan oleh bangsa Indonesia saat ini. Alat konstruksi jaman modern ini berukuran besar, dan diopeasikan tanpa harus menggunakan tenaga yang besar. Dikuatkan dengan caption: Bahan yang digunakan pun sudah berubah, tidak lagi menggunakan bambu, kayu atau bahan alami lainnya yang ringan (p.308). Memperlihatkan alat konstruksi yang dimiliki bangsa Indonesia sejak dulu kala, cangkul. Penjelasan dalam caption: Memperlihatkan dibalik kesederhanaan cangkul namun menyimpan kelebihannya yang bersifat fleksibel (p.309).

Spektrum : Orang di dalam kabin sedang mengooperasikan alat canggih terlihat serius namun gestur badannya tidak menunjukkan sedang mengerahkan tenaga yang besar. Sementara orang yang di sebelahnya antusias dan terlihat hendak memasuki kabin kendali mesin. Pakaian keduanya rapih, berkemeja dan bercelana panjang. Pria yang di luar kabin menggunakan topi proyek (p.309). 

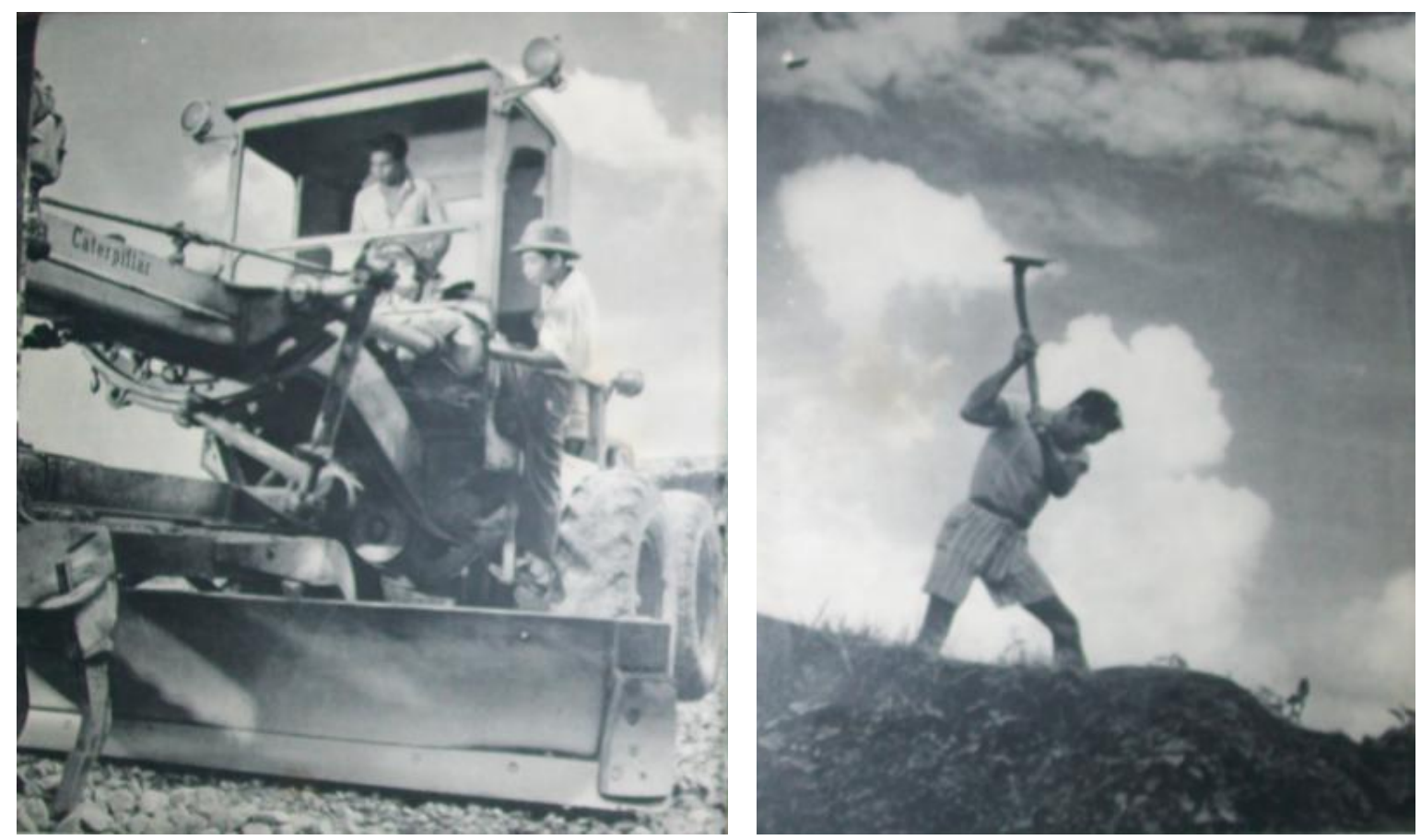

Gambar 5. Foto Pemanfaatan SDA (kanan p.308, kiri p.309, 2012)

Pria berbadan tegap, rambut pendek, berpakaian kaos dan celana pendek Gestur pria yang mengayunkan cangkulnya tinggi - tinggi, kepala menunduk (p.309).

Spektator - Studium : Menunjukkan banyak hal positif yang ditawarkan oleh alat konstruksi yang canggih ini. Walaupun membutuhkan keseriusan yang tinggi, pekerjaan ini merupakan sesuatu yang menyenangkan. Terlihat pada ekspresi pria muda di luar kabin yang terlihat antusias dan seperti sedang main - main. Sesuai dengan caption yaitu menjadikan kerja lebih cepat (p.308). Menggambarkan seorang pria yang bekerja keras, menggunakan cangkul. Sebagai alat sederhana, cangkul untuk orang yang sederhana. Diperkuat pada kalimat terakhir caption: karena sifatnya yang sederhana itu, cangkul alat yang sangat berguna, perlambang pekerjaan petani untuk memenuhi kebutuhan hidup : makan (p.309).

Spektator - Punctum : Bayangan yang ada di dalam kabin, sebelah pria yang mengoperasikan kabin.Apakah ia pendonor teknologi alat canggih tersebut? Dihubungkan dengan tulisan Caterpillar pada mesin konstruksi itu. Apakah pemilik bayangan itu adalah bangsa asing yang berhubungan dengan tulisan Caterpillar itu ? (p.308). Posisi kepala yang menunduk, menunjukkan kekalahan atau rasa tidak percaya diri (p.309).

\section{KESIMPULAN}

Editor-penyusun memilih untuk membagi tema berdasarkan urutan posisi wilayah/pulau yang ada. Dimulai dari Sumatera, Kalimantan, Sulawesi, Nusa Tenggara, Jawa dan berakhir di Jawa Barat. Hal ini 
merupakan cara untuk menutup kekosongan pada masa revolusi fisik. Karena, bila mengacu pada kronologi sejarah Indonesia, penghilangan fase itu akan terasa mengganggu. Sementara beberapa foto justru diambil saat Indonesia belum merdeka, berarti akan terasa ada bagian yang hilang.

Peran editor sebagai sutradara yang konsisten menampilkan informasi "kena di hati" dan "Indonesia dengan identitas baru yang berbeda dengan buku tentang Indonesia yang dibuat bangsa asing", dilakukan dengan cara menampilkan kontras antara sudut pandang bangsa asing / Eropa dengan kondisi yang sedang dijalani Indonesia saat itu. Kontras tersebut dilakukan dengan cara :

- Memilihyang foto kontras satu sama lain pada sekuens yang berurutan sehingga terlihat perbedaan antara satu dengan lainnya.Semakin kuat tingkat kontras nya, maka akan semakin kuat kesan yang tertinggal dibenak pembacanya. Sekuens berurutan secara recto - verso atau recto - verso dengan jeda satu halaman dan berlanjut di halaman berikutnya.

- Membuat caption foto dengan bahasa yang santai namun menuntun pembaca untuk mencari objek yang dibahas.Mengingat beberapa foto memiliki latar yang padat, agak sulit menemukan keunikan (punctum) dari foto tersebut. Artinya spektator dituntun oleh operator melalui caption foto yang kadang tegas, kadang samar mengarahkan pandangan pada punctum nya.

- Beberapa punctum yang membawa spektator pada diskusi lebih lanjut mengenai keadaaan Indonesia saat itu, dibiarkan terlepas dari captionnya. Bahkan untuk tema yang sensitif seperti agama Islam, politik (siapa penguasa/pemilik sebenarnya) diberi caption yang menghindari apa yang dipikirkan spektator.

Informasi yang ditemukan Spektator Studium, berdasarkan pengelompokan temaadalah :

- Kekayaan - keindahan alam : Alam Indonesia luas dan banyak wilayah belum tersentuh.

- Pemanfaatan SDA : Indonesia sudah mulai menggunakan teknologi termaju pada masa itu dan siap menyongsong masa depan dengan optimisme itu.

- Perubahan proses politik : sudah masuk era demokrasi modern, dan itu bisa dilewati dengan baik, lega.

- Perubahan teknologi alat kerja : Indonesia mungkin akan menggunakan teknologi canggih bersamaan dengan alat sederhana yang digunakan oleh sebagian besar rakyatnya, mungkin keduanya bisa berdampingan.

Penemuan punctum oleh spektator cenderung diarahkan oleh operator. Sehingga kesan yang diharapkan muncul di benak spektator dapat dikendalikan oleh operator. Kondisi ini menunjukkan kuatnya sistem penyuntingan yang dilakukan oleh 
editor-penyusun. Karena pada isu isu yang sudah menjadi kebenaran umum spektator diberi petunjuk berupa caption menuju punctum. Tetapi ketika menyentuh isu sensitifcaption dibuat terlepas dari punctumnya dan membiarkan spektator menebak sendiri

\section{DAFTAR PUSTAKA}

Douwes Dekker, N.A., 1951. Tanah Air Kita, N.V.Van Hoeve, Bandung

Noth, Winfred

1990. Handbook of Semiotics, Indiana University Press,

Sobur M.Si, Drs.Alex

2006. Semiotika Komunikasi, Remaja Rosdakarya, Bandung Schneider, Adam Laurie
1996 The Methodologies of Art, An Introduction, UK:Westview Press.

Bungin S.Sos, M.Si, Prof.Burhan 2007 Penelitian Kualitatif komunikasi, ekonomi, Kebijakan Publik, dan Ilmu Sosial lainnya, Kencana Prenada Media Grup, Jakarta. www.aber.ac.uk/media/Documents/S4 B/sem08c.html untuk Chandler, Daniel, 2000, versi e-book dari Semiotics for Beginner, http://georgepowell.wordpress.com/2 008/07/01/studium-and-punctum/ www.ibvh.com/web2/about.php http://rmc.library.cornell.edu/ 2002 Division of Rare and Manuscript Collections, Cornell University Libray 